\title{
IDENTIFIKASI POTENSI ENZIM AGARASE YANG DIHASILKAN OLEH KAPANG HASIL ISOLASI DARI Caulerpa sp.
}

\author{
Oleh \\ Bertoka Fajar SP Negara ${ }^{1}$, Mujizat Kawaroe ${ }^{2}$ dan Dwi Setyaningsih ${ }^{3}$ \\ ${ }^{1}$ Program Studi Ilmu Kelautan. Universitas Bengkulu, Bengkulu. \\ ${ }^{2}$ Departemen Ilmu Kelautan, Institut Pertanian Bogor, Bogor \\ ${ }^{3}$ Departemen Teknologi Industri Pertanian, Institut Pertanian Bogor, Bogor \\ Email:bfsp_negara@yahoo.com \\ Received February 2016, Accepted March 2016
}

\begin{abstract}
ABSTRAK
Kapang adalah mikroorganisme yang dapat diisolasi dari beberapa sumber seperti sedimen, air, serasah, rumput laut dan masih banyak lagi. Kapang dapat menghasilkan enzim yang memiliki banyak fungsi dan keuntungan. Tujuan dari penelitian ini adalah untuk mengisolasi kapang dari sedimen, serasah, dan air yang berasal dari sekitar lingkungan Caulerpa sp. Dan mengidentifikasi potensi enzim agarase yang dihasilkan. Sebanyak 41 isolat berhasil diisolasi. 5 isolat memiliki aktivitas enzim yang potensial (A10, A11, A13, SUC 7 dan SEC 8). Isolat $\mathrm{A} 13$ adalah isolat terbaik karena memiliki aktivitas agarase tertinggi dan waktu pertumbuhan yang lebih cepat daripada yang lain.
\end{abstract}

Kata kunci : Isolat, agarase, enzyme, caulerpa sp., dan kapang

\begin{abstract}
Mold are microorganisms which could be isolated from several sources, such as sediment, water, litter, seaweed and many more. Mold can produce enzymes which has many benefit. The aims of study was to isolated mold of sediment, litter and water around Caulerpa sp. and identify potential enzyme agarase that produced by theme self. Totally 41 isolates were isolated. 5 isolates have the potential agarase activity (A10, A11, A13, SUC 7 and SEC 8). Isolates A13 is the most potent isolates because it has the highest agarase activity and time growing is more fastly than others.
\end{abstract}

Key words: Isolates, agarase, enzymes, caulerpa sp. and mold. 


\section{PENDAHULUAN}

Kapang adalah fungi multiseluler yang mempunyai filamen, dan pertumbuhannya pada media mudah dilihat karena penampakannya yang berserabut seperti kapas. Pertumbuhan awal dari kapang pada umumnya berwarna putih, tetapi jika spora telah tumbuh akan terbentuk berbagai warna tergantung dari jenis kapang (Pelczar 2005). Beberapa penelitian mengenai kapang telah berhasil mengisolasi dari berbagai lingkungan seperti tanaman (llyas 2006), sarang rayap (Purwadaria et al., 2003), dan lingkungan laut (Nursid et al., 2011). Kapang memiliki beberapa peranan baik dalam di alam maupun untuk keperluan bioprospeksi.

Secara alami kapang berperan sebagai dekomposer serasah untuk mendegradasi selulosa, hemiselulosa dan lignin (Gosh and Gosh, 1992). Selain itu kapang dapat menghasilkan metabolit sekunder termasuk senyawa anti kanker, antibiotik dan enzim (llyas 2006), yang dapat dimanfaatkan untuk berbagai kepentingan. Penelitian mengenai bioprospeksi kapang yang diisolasi dari lingkungan laut di Indonesia bisa dikatakan masih terbatas baik biodiversitas maupun kemodiversitasnya. Beberapa penelitian dalam bidang ini misalnya dilakukan oleh Namikoshi et al. (2001); Proksch et al. (2003); Chasanah et al. (2009); dan Pratitis et al. (2009).

Enzim merupakan biokatalisator yang mempercepat jalannya reaksi tanpa ikut bereaksi. Banyak jenis enzim yang telah diketahui manfaatnya dan digunakan dalam berbagai bidang (Fu dan Kim 2010; Faturrahman et al., 2011; Purwadaria et al., 2003). Agarase merupakan salah satu enzim yang digolongkan dalam dua katagori yaitu $\alpha$-agarase dan $\beta$-agarase. Agarase dapat dimanfaatkan dalam industi kosmetik dan makanan. Manfaat lain dari agarase yaitu dapat menghidrolisis agar menjadi oligosakarida (Nahak et al., 2011). Sejauh ini agarase telah diisolasi dari beberapa genera mikroorganisme yang berasal dari air laut, sedimen dan lingkungan laut (Fu dan Kim 2010). Enzim yang dihasilkan kapang antara lain sellulase, esterase, peroksidase, lipase, silase, dan amilase (Anindyawati, 2003).

Penelitian untuk mengisolasi kapang dari lingkungan laut serta mengeidentifikasi potensi enzim yang dihasilkannya masih belum banyak yang melakukan. Penelitian ini bertujuan untuk mengisolasi kapang dari Caulerpa sp. dan mengindentifikasi potensi enzim agarase yang dihasilkannya.

\section{MATERI DAN METODE}

\section{Lokasi sampling}

Sampel diambil di perairan Pulau Pari, Jakarta. Sampel yang diambil meliputi air, substrat dan serasah yang ada di sekitar Caulerpa sp. Sampel yang diperoleh dimasukkan ke dalam kantong plastik steril, diberi label dan segera dipreservasi pada suhu dingin dengan menggunakan es batu.

\section{Isolasi dan purifikasi kapang}

Isolasi dilakukan dengan menggunakan media PDA dengan komposisi $35 \mathrm{gr}$ PDA instan yang dicampur kedalam $1 \mathrm{~L}$ air laut. Isolasi kapang dilakukan dengan mengggunakan metode Pikoli et al., (2000) yang dimodifikasi. Secara aseptis, sampel serasah yang diperoleh terlebih dahulu disemprot dengan alkohol $70 \%$ dan di potong kecil-kecil, kemudian ditempatkan ke dalam petri yang berisi media. Sedangkan untuk sampel air laut dan sedimen dimasukan kedalam tabung reaksi yang berisi $5 \mathrm{ml}$ air laut steril dan dilakukan pengenceran hingga 
$10^{-3}$, kemudian hasil dari tiap-tiap pengenceran diambil sebanyak $0,1 \mathrm{ml}$ ditempatkan ke dalam petri yang berisi media. Petri diinkubasi pada suhu ruang $\left(27-29^{\circ} \mathrm{C}\right)$ selama 3-7 hari. Setiap kapang yang tumbuh pada cawan petri kemudian dipindah ke petri yang baru berdasarkan bentuk dan warna hifa. Proses isolasi dilakukan secara berulang hingga diperoleh 1 jenis kapang tunggal (strain murni) dari masing-masing sampel.

\section{Uji aktivitas enzim agarase}

Uji kualitatif dari enzim agarase dilakukan dengan menggunakan metode pewarnaan lugol iodin. Zona bening yang dihasilkan disekitar koloni kapang menunjukan adanya produksi enzim agarase. Zona bening yang dihasilkan diukur dan dihitung dengan menggunakan rumus indeks agarase (Kader dan Omar 1998). Isolat yang memiliki nilai zona bening tertinggi akan dilakukan pengukuran kurva pertumbuhannya dan identifikasi morfologi.

$$
\text { Indeks agarase }=\frac{\text { diameter zona bening }(\mathrm{mm})-\text { diameter koloni }(\mathrm{mm})}{\text { diameter koloni }(\mathrm{mm})}
$$

\section{Pengukuran kurva pertumbuhan}

Kurva pertumbuhan dari isolat diukur dengan menggunakan metode kamar hitung (counting chamber), dalam metode ini akan dilakukan pengamatan langsung dengan menggunakan mikroskop. Pengukuran kurva pertumbuhan dilakukan dengan mengkultur 2 lup isolat di dalam $150 \mathrm{~mL}$ media Potato dextrose liquid (PDL) dan diinkubasi selama 7 hari dengan rentang waktu sampling 24 jam untuk diukur jumlah spora dengan menggunakan Improved Neubauer. Jumlah spora yang didapatkan dimasukan kedalam rumus (Joklik 1992):

$$
\frac{\text { Jumlah spora terhitung }}{\text { Volume kamar yang digunakan }} \times \text { Jumlah larutan induk }
$$

\section{HASIL DAN PEMBAHASAN}

Total isolat yang diperoleh sebanyak 41 isolat terdiri dari 21 isolat berasal dari air, 13 isolat berasal dari substrat dan 8 isolat berasal dari serasah (Gambar 1). Kapang yang berhasil diisolasi dari air memiliki jumlah yang lebih banyak bila dibandingkan dengan yang lain. Sementara kapang yang berhasil diisolasi dari serasah memiliki jumlah yang paling rendah setelah kapang yang berhasil diisolasi dari substrat. Pada dasarnya mikroorganisme yang berhasil diisolasi dari air memiliki jumlah yang lebih banyak dibandingkan dengan tanah (Nuchsin 2007). 


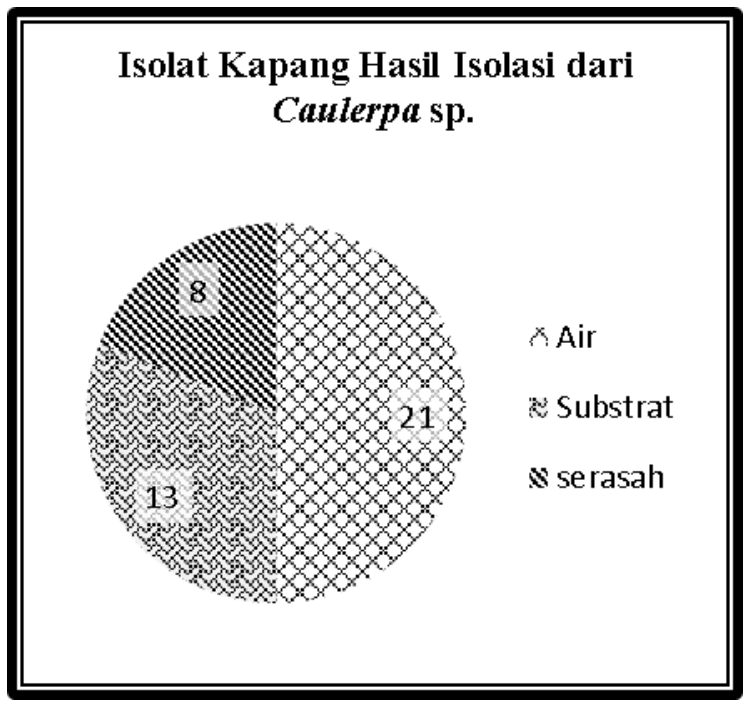

Gambar 1. Jumlah isolat kapang yang diisolasi dari air, substrat dan serasah Caulerpa sp.

Hasil uji aktivitas agarase (Tabel 1) terhadap isolat yang berasal dari air memperlihatkan bahwa $66 \%$ dari total isolat memiliki aktivitas. Dimana kisaran nilai rata-rata indeks agarase yang dihasilkan sebesar $0.85 \mathrm{~mm}-9.28 \mathrm{~mm}$. Ratarata indeks agarase tertinggi dihasilkan oleh isolat $A 10, A 11$ dan $A 13$ dengan nilai sebesar $9.28 \mathrm{~mm}, 4.48 \mathrm{~mm}$ dan $7.27 \mathrm{~mm}$ secara berurutan. Sementara untuk hasil uji aktivitas yang dihasilkan oleh isolat yang berasal dari substrat diketahui sebesar $61 \%$ dari total isolat memiliki aktivitas. Nilai kisaran rata-rata indeks agarase yang dihasilkan sebesar $0.48 \mathrm{~mm}-4.69 \mathrm{~mm}$. SUC 7 merupakan isolat yang menghasilkan nilai indeks rata-rata agarase tertinggi yaitu sebesar $4.69 \mathrm{~mm}$. Sedangkan untuk isolat yang berasal dari serasah memiliki aktivitas agarase sebesar $50 \%$ dari total isolat. Kisaran nilai rata-rata indeks agarase dari isolat yang dihasilkan sebesar $0.25 \mathrm{~mm}-4.28 \mathrm{~mm}$. Adanya aktivitas agarase ditunjukan dengan zona bening yang dibentuk oleh isolat ketika ditambahkanya lugol iodin (Fu dan Kim 2010).

Tabel 1. Nilai rata-rata indeks agarase dari hasil uji aktivitas isolat kapang yang diisolasi yang diisolasi dari air, substrat dan serasah Caulerpa sp.

\begin{tabular}{cccccc}
\hline Isolat & $\begin{array}{c}\text { Rata-rata indeks } \\
\text { agarase }\end{array}$ & Isolat & $\begin{array}{c}\text { Rata-rata indeks } \\
\text { agarase }\end{array}$ & Isolat & $\begin{array}{c}\text { Rata-rata } \\
\text { indeks } \\
\text { agarase }\end{array}$ \\
\hline A1 & 1,41 & SUC1 & 0,58 & SEC1 & 0,25 \\
A2 & 0,00 & SUC2 & 0,48 & SEC2 & 3,48 \\
A3 & 1,74 & SUC3 & 0,00 & SEC3 & 0,00 \\
A4 & 1,12 & SUC4 & 0,00 & SEC4 & 0,00 \\
A5 & 0,85 & SUC5 & 0,00 & SEC5 & 1,73 \\
A6 & 3,67 & SUC6 & 4,20 & SEC6 & 0,00 \\
A7 & 3,41 & SUC7 & 4,69 & SEC7 & 0,00 \\
A8 & 0,00 & SUC8 & 0,75 & SEC8 & 4,95 \\
A9 & 0,00 & SUC9 & 2,74 & & \\
A10 & 9,28 & SUC10 & 0,82 & &
\end{tabular}




$\begin{array}{llll}\text { A11 } & 4,48 & \text { SUC11 } & 3,99 \\ \text { A12 } & 1,35 & \text { SUC12 } & 0,00 \\ \text { A13 } & 7,27 & \text { SUC13 } & 0,00 \\ \text { A14 } & 1,26 & & \\ \text { A15 } & 4,15 & & \\ \text { A16 } & 0,00 & & \\ \text { A17 } & 1,15 & & \\ \text { A18 } & 0,00 & & \\ \text { A19 } & 0,00 & & \\ \text { A20 } & 0,00 & & \\ \text { A21 } & 0,00 & & \end{array}$

Secara keseluruhan hanya terdapat 5 isolat yang memiliki aktivitas agarase yang dilihat dari nilai indeks rata-rata agarase yaitu A10, A11, A13, SUC 7 dan A13. Pengamatan terhadap kurva pertumbuhan dari masing-masing isolat memperlihatkan waktu yang berbeda-beda untuk memcapai fase stasioner. Isolat A10 memerlukan waktu selama 4 hari, A11 memerluka waktu 3 hari, A13 memerlukan waktu 3 hari, SUC 7 memerluka waktu 6 hari dan SEC 8 memerlukan waktu 5 hari. Bila kaitkan dengan hasil uji aktivitas agarase maka isolat $\mathrm{A} 13$ merupakan isolat yang potensial dimana memiliki nilai rata-rata indeks agarase yang tinggi serta waktu untuk memcapai fase stasioner lebih cepat bila dibandingkan dengan yang lain. Isolat yang potensial adalah isolat yang memiliki waktu untuk tumbuh lebih cepat dan memiliki aktivitas yang tinggi.

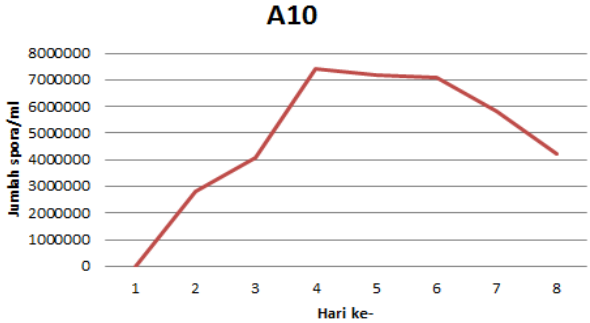

A13

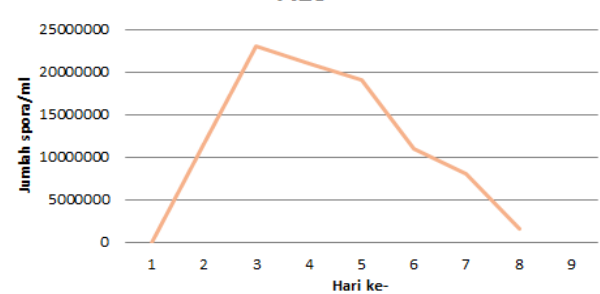

A11

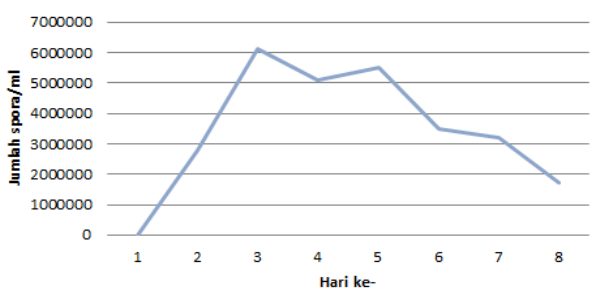

SUC7

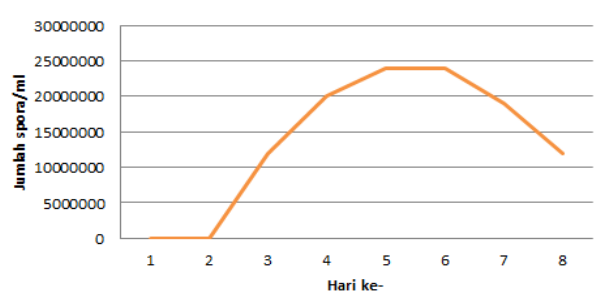

SEC8

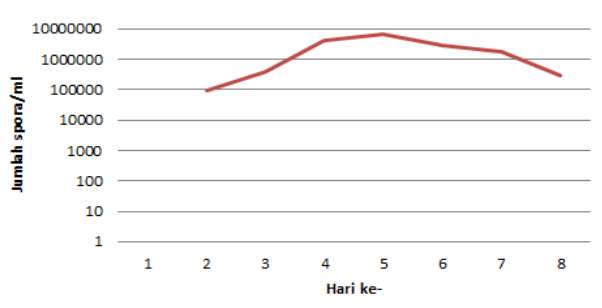

Gambar 3. Kurva pertumbuhan kapang yang diisolasi dari air, substrat dan serasah Caulerpa sp. 


\section{KESIMPULAN}

Berdasarkan hasil yang didapatkan diketahui bahwa isolat A13 merupakan isolat yang paling potensial karena memiliki nilai rata-rata indeks agarase tertinggi serta memiliki waktu pertumbuhan yang cepat.

\section{UCAPAN TERIMAKASIH}

Penulis mengucapkan terimakasih kepada Pusat Studi Surfaktan dan Bioenergi, IPB Bogor atas kesempatan yang diberikan kepada penulis untuk dapat mengerjakan penelitian ini.

\section{DAFTAR PUSTAKA}

Anindyawati, T. 2003. .Mikrobia endofit: Manfaat dan cara mengisolasinya. Alam Kita. 12 (1): 11-14.

Chasanah, E., Januar, H.I., Irianto, H.E., Bourne, D., Liptrot, C., and Wright, A. 2009. Screening of anticancer activity of fungi derived from Indonesia marine sponges. Journal of marine and fisheries postharvest and biotechnology, special edition in conjuction with World Ocean Conference 2009. p. 1-8.

Faturrahman., A. Meryandini., M. Z. Junior., dan I. Rusmana. 2011. Isolation and identification of an agar-liquefying marine bacterium and some properties of its extracellular agarases. Biodiversitas. 12 (4): 192-197.

Fu, X. T., dan S. M. Kim. 2010. Agarase: Review of Major Sources, Categories, Purification Method, Enzyme Characteristics and Applications. Mar. Drugs. 8: 200-218.

Gosh, B.K., dan Gosh, A. 1992. Degradation of Cellulose by Fungal Cellullase. In Microbial Degradation of Natural Products, ed. G. Winkelmann. VCH Publishers, Inc., New York, pp.84-126.

llyas, Muhammad. 2006. Isolasi dan Identifikasi Kapang pada Relung Rizosfir Tanaman di Kawasan Cagar Alam Gunung Mutis, Nusa Tenggara Timur. Biodiversitas. 7(3): 216-220.

Nahak, Sabitri., Gayatri Nahak., Itishree Pradhan., dan R.K. Sahu. 2011. Bioethanol from Marine Algae: A Solution to Global Warming Problem. J. Appl. Environ. Biol. Sci., 1(4): 74-80.

Namikoshi, M., Akano, K., Kobayashi, H., Koike, Y., Kitazawa, A., Rondonuwu, A.B., and Pratasik, S.B. 2002. Distribution of marine filamentous fungi associated with marine sponges in coral reefs of Palau and Bunaken Island, Indonesia. Journal of Tokyo University of Fisheries. 88: 15-20.

Nursid, M., E, Chasanah., Murwantoko., dan S,Wahyuon. 2011. Penapisan Kapang Laut Penghasil Senyawa Sitotoksik dari Beberapa Perairan Di Indonesia. Jurnal Pascapanen dan Bioteknologi Kelautan dan Perikanan. 6 (1): 45-56.

Pervez1 M. R, M. Musaddiq, dan Prashant V. Thakare. 2012. In-vitro antimicrobial studies of isolated myrothecium spp mrp001 against human pathogens. International Journal of Basic and Applied Medical Sciences. 2(3): 228-236.

Pratitis, A., Chasanah, E., and Nursid, M. 2009. Skrining aktivitas sitotoksik dan peredaman radikal bebas DPPH ektrak marine fungi yang diisolasi dari spons asal perairan Wakatobi. Prosiding Seminar Nasional Pascapanen dan Bioteknologi Kelautan dan Perikanan, Jakarta. 
Proksch, P., Ebel, R., Edrada, R.S., Schupp, P., Lin W.H., Sudarsono., Wray, V., and Steube, K. 2003. Detection of pharmacologically active natural products using ecology, selected examples from Indopacific marine invertebrates and sponge-derived fungi. Pure Appl. Chem. 75: 343-352.

Purwadaria, Tresnawati., P. A. Marbun., A. P. Sinurat., dan P. P. Ketaren. 2003. Perbandingan Aktivitas Enzim Selulase dari Bakteri dan Kapang Hasil Isolasi dari Rayap. JITV. 8 (4): 213-219.

Kader AJ, dan O. Omar. 1998. Isolation of cellulolytic fungi from Sayap-Kinabalu Park, Sabah. Serawak. J Biodiversity Bio-Conserv (ARBEC): 1-6.

Pikoli. M. ,R. P., Aditiawati., D.I. Astuti. 2000. Isolasi Bertahap dan Indentifikasi Isolat Bakteri Termofilik Pendegradasi Minyak Bumi dari Sumur Banko. LaporanPenelitian Jurusan Biologi, ITB, Bandung.

Joklik, Wolfgang K. 1992. Zinser Microbiologi 20th edition. Connecticut: Appleton \&lange.

Gandjar, I., R.A. Samson, K. van den Tweel-Vermeulen, A. Oetari and I. Santoso. 1999. Pengenalan kapang tropik umum. Jakarta: Yayasan Obor Indonesia.

Nuchsin, R. 2007. Distribusi Vertikal Bakteri dan Kaitannya dengan Konsentrasi Klorofil-A Di Perairan Kalimantan Timur. Makara, Sains. 11 (1): 10-15. 